\title{
Effects of The First 1000 Days of Life Module For Premarital Women Against Knowledge and Attitudes to Prevent Stunting
}

\author{
Zubaeda $^{1}$, Runjati ${ }^{2}$, Suhartono ${ }^{3}$ \\ ${ }^{1,2}$ Program Pascasarjana Magister Terapan Kebidanan, Poltekkes Kemenkes Semarang \\ ${ }^{3}$ Fakultas Kesehatan Masyrakat, Universitas Diponegoro \\ *zubaeda95@gmail.com
}

\begin{abstract}
The first 1000 days of life period is the most frequent period of stunting as well as the best period to prevent and improve the stunting condition, so it needs optimal preparation before entering this period which can be applied to premarital women. It is necessary to have an independent learning tool that is feasible and can be used for premarital women in preparing themselves before entering the first 1000 days of life period. This study aims to analyze the effect of giving first 1000 days of life modules to the knowledge and attitude of stunting prevention in Premarital women. This type of research is quasi-experimental pre test-post test with control group design. The number of samples is 60 premarital women divided into two groups. the intervention group was given a premarital class and module, while in the control group was given a premarital class only. The giving of premarital classes and modules has the effect of increasing knowledge and attitudes of stunting prevention in premarital women ( $\mathrm{p}$ value $0.001<0.05$ ). Different test results show that giving pre-marital classes plus modules has more effect on increasing knowledge ( $\mathrm{p}$ value 0.002) and attitude ( $\mathrm{p}$ value 0.02). The First 1000 days of life modules has more effect on increasing knowledege and attitude of stunting prevention compare premarital class only.
\end{abstract}

Keywords: Stunting, First 1000 Days of Life Module, Premarital Women 


\section{STRADA Jurnal Ilmiah Kesehatan}

DOI: $10.30994 /$ sjik.v9i2.332

ISSN: 2252-3847 (print); 2614-350X (online)

Vol.9 No.2 November 2020 Page.515-522

\section{BACKGROUND}

Children are the nation's assets in the future. The condition of Indonesia's human resources in the future will greatly affect if at present there are many Indonesian children who suffer from stunting. Stunting or short toddlers is a chronic nutritional problem in infants characterized by height less than the ideal size or standard (Nurhayati, 2019). Until now, stunting is still a major nutritional problem in the world. Asia accounts for half $(55 \%)$ of the total stunting toddler in the world, while a third $(33 \%)$ are in Africa. Indonesia itself is recorded as the country with the third highest contributor to stunting prevalence in the Southeast Asian region (Pusat Data dan Informasi Kementerian Kesehatan RI, 2018).

Several studies have been conducted to find the best effort to reduce the factors causing stunting. A study states that the optimal health promotion strategy through quality timely and repeated counseling to mothers is able to significantly change the practice of breastfeeding and supplementary feeding, so that health promotion is an effort that can be done to reduce the causes of stunting (Sanghvi et al., 2016). Other research also shows that after promoting optimal feeding and nutrition, stunting reduces in children 6-59 months by $10.5 \%$ - $18.0 \%$ (Haselow, Stormer, \& Pries, 2016).

The results of a study conducted in East Nusa Tenggara Indonesia, concluded that stunting handling focused on the conception period and afterwards such as the Supplementary Feeding Program and the improvement of toddlers' posyandu services have not been able to reduce the prevalence of stunting and even decrease declining is still very slow. This research suggests that stunting prevention must be carried out since the preconception (Jap, Sumarmi, \& Damayanti, 2019). This is supported by research results which show that increasing nutritional status during preconception will be followed by increased fetal growth and reducing the potential for stunting when a child is 2 years old (Young et al., 2017).

The Ministry of Health of the Republic of Indonesia itself said that in an effort to reduce the prevalence of stunting, the interventions provided were more focused on the period of First 1000 Days of Life, because this period is the most frequent period of stunting as well as the best period (window opportunity) to prevent and improve the stunting condition. The First 1000 Days Of Life period starts from the beginning of conception until the child is 2 years old or 270 days during pregnancy and 730 days from the baby being born (Pusat Data dan Informasi Kementerian Kesehatan RI, 2018). Because this period starts from the beginning of conception, if the intervention is carried out during pregnancy, this is considered to be too late. So there needs to be an early effort made before entering the conception period through health promotion and education at premarital women. One of the appropriate educational media that can be used as an independent learning tool for premarital women regarding the period of First 1000 Days of Life is through a module. The module is able to reduce the time limitations between health workers and premarital women because women can study independently

\section{METHODS}

The method used in this research is the Research and Development (R\&D) method by adopting the simplified Borg and Gall model (Amri, 2013): 


\section{STRADA Jurnal Ilmiah Kesehatan}

DOI: $10.30994 /$ sjik.v9i2.332

ISSN: 2252-3847 (print); 2614-350X (online)

Vol.9 No.2 November 2020 Page.515-522

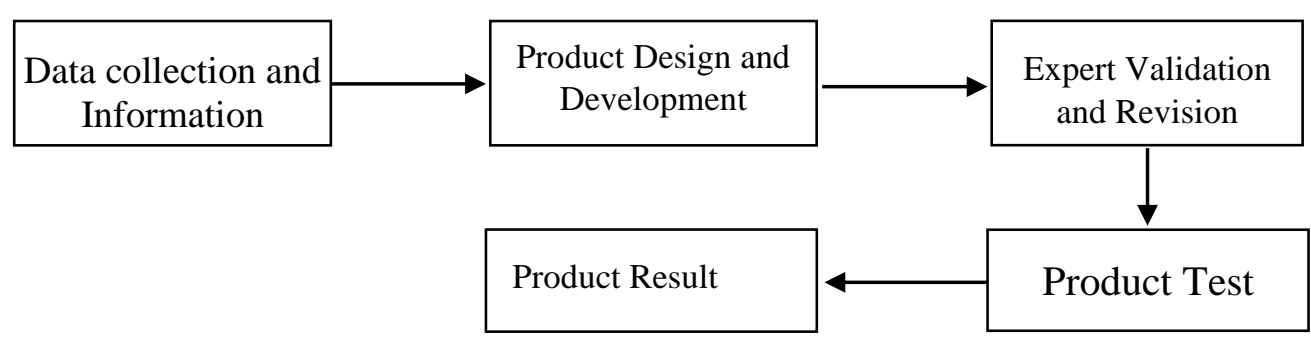

Figure 1. Research and Development Method Flow

The initial module development was carried out by gathering information from various sources, namely from literature to interviews with the health department, puskesmas, and bride and groom in order to obtain modules that are relevant to the user. After the module is developed, the module is then assessed by material experts, health promotion experts and midwives. The product test phase uses a type of quasi-experimental research with pre-post control group design. The population in this study were all premarital women in the working area of Srondol health center. The sample in this study amounted to 60 women who were divided into two groups. the treatment group was given a premarital class and module package while in the control group was given a premarital class only. The treatment is given for 5 weeks. The study was conducted in early February to mid-March 2020.

The sample in this study is a sample that comply the inclusion criteria that are able to read and write, aged $\geq 19$ years, and high school final education. While the exclusion criteria in this study are: forced marriage, pregnancy before marriage, and income $\leq \mathrm{Rp}$. 1000,000. Data collection techniques using a questionnaire that has been tested for validity and reliability. To analyze the effect before and after treatment in each group was used paired T-test, whereas to analyze the difference in effect after treatment was used independent T-test test.

\section{RESULT}

The First 1000 days of life module consists of four modules, That Are Module 1 : Pregnancy Preparation, Module 2 : Pregnancy Period, Module 3 : Labor, Postpartum and Breastfeeding Period, Module 4 : 0-24 months of Baby Period. The four sets of modules are included in a box so that they become a single unit and are given a cover with the title First 1000 Days of Life Module for Premarital Women. Each module consists of an introduction, a description of the material, a summary, an exercise, an answer key, feedback and a bibliography. This module is divided into four sets with the consideration that learning will be carried out continuously in accordance with the stages in the period of First 1000 Days of Life.

Table 1

Frequency Distribution of Respondent Characteristics

\begin{tabular}{|c|c|c|c|c|c|}
\hline \multirow{3}{*}{ Characteristics } & \multicolumn{4}{|c|}{ Gorup } & \multirow{3}{*}{$p$-value } \\
\hline & \multicolumn{2}{|c|}{ Intervention } & \multicolumn{2}{|c|}{ Control } & \\
\hline & $\mathrm{N}$ & $\%$ & $\mathrm{~N}$ & $\%$ & \\
\hline \multicolumn{6}{|l|}{ Education Level } \\
\hline Highschool & 11 & 36,7 & 12 & 40 & $0,063^{*}$ \\
\hline Bachelor/Vocational & 19 & 63,3 & 18 & 60 & \\
\hline
\end{tabular}




\section{STRADA Jurnal Ilmiah Kesehatan}

DOI: $10.30994 /$ sjik.v9i2.332

ISSN: 2252-3847 (print); 2614-350X (online)

Vol.9 No.2 November 2020 Page.515-522

\begin{tabular}{lccccc}
\hline Income : & & & & & \\
Rp 1000.000-2000.000 & 15 & 50 & 12 & 40 & $0,676^{*}$ \\
>Rp 2000.000-3000.000 & 11 & 36,7 & 13 & 43,3 & \\
> Rp 3000.000 & 4 & 13,3 & 5 & 16,7 & \\
\hline * Chi-Square Test & & & & &
\end{tabular}

Based on table 1, the majority of respondents in both groups have a secondary education level, while based on the characteristics of income the results obtained in the treatment group most $(50 \%)$ have income of 1-2 million and in the control group most $(43.3 \%)$ have income 2-3 million. The results of the different proportions test using chisquare test obtained $\mathrm{p}$ value $0.063>0.05$ and $0.67>0.05$ which means there are no differences in the characteristics of education and income in both group.

Table 2

Normality Test Value of Knowledge and Attitudes Respondents

\begin{tabular}{lll}
\hline \multirow{2}{*}{ Variable } & Intervention Group & Control Group \\
& & \\
& $\rho$-value $>0.05$ & $\rho$-value $>0.05$ \\
\hline Knowledge Pre test & 0,067 & 0,254 \\
Attitude Pre Test & 0,113 & 0,083 \\
Knowledge Post Test & 0,198 & 0,083 \\
Attitude Post Test & 0,233 & 0,161 \\
\hline
\end{tabular}

Based on table 2 after test of normality used Shapiro Wilk test the result showed that all values $\rho>0.005$ so it can be concluded that the data in this study are normally distributed.

Table 3

The Effect First 1000 Days of Life Modules Against Knowledge of Premarital Women About Stunting Prevention

\begin{tabular}{cccc}
\hline \multirow{2}{*}{ Knowledge Score } & \multicolumn{2}{c}{ Group } & \multirow{2}{*}{-value $<0.05$} \\
\cline { 2 - 3 } & Intervention $(n=30)$ & Control $(n=30)$ & $0,752^{\mathrm{d}}$ \\
Pre & $48,83^{\mathrm{a}} \pm 8,57 ; 47,10^{\mathrm{b}}$ & $48,04 \pm 10,47 ; 47,1$ & $0,002^{\mathrm{d}}$ \\
Post & $65,69^{\mathrm{a}} \pm 9,54 ; 64,7$ & $57,44 \pm 10,44 ; 52,90$ & $0,003^{\mathrm{d}}$ \\
Delta & $16,65^{\mathrm{a}} \pm 8,577 ; 17,60$ & $9,40 \pm 9,85 ; 5,90$ & \\
\hline$P$-value $<0.05$ & $0,001^{\mathrm{c}}$ & $0,001^{\mathrm{c}}$ & \\
\hline $\mathrm{a}=$ Mean \pm Standar Deviasi & $\mathrm{c}=$ paired T-test & \\
$\mathrm{b}=$ Median & $\mathrm{d}=$ Independent T-test
\end{tabular}

Based on table 3, after analysis using paired T-test test the result was obtained $\mathrm{P}$ value was $0.001<0.05$ which means that the First 1000 Days of Life Module and the premarital class are effective in increasing knowledge of premarital about stunting prevention. Meanwhile, after the after a different test used independent T-Test the result showed $p$ value $0.002<0.05$ which means that there are differences effect between the two groups after the intervention was given, where based on the mean rank of the treatment group is 65.69 greater than the control group that is 57.44 , so it can be concluded that the giving modules is more effective in increasing the knowledge of premarital women about stunting prevention compared to premarital classes only. 


\section{STRADA Jurnal Ilmiah Kesehatan}

DOI: $10.30994 /$ sjik.v9i2.332

ISSN: 2252-3847 (print); 2614-350X (online)

Vol.9 No.2 November 2020 Page.515-522

Table 4

The Effect First 1000 Days of Life Modules Against Attitude of Premarital Women About Stunting Prevention

\begin{tabular}{lccc}
\hline \multirow{2}{*}{ Attitude Score } & \multicolumn{2}{c}{ Group } & \multirow{2}{*}{-value $<0.05$} \\
\cline { 2 - 3 } & Interventions $(n=30)$ & Control $(n=30)$ & $0,211^{\mathrm{d}}$ \\
Pre & $57,19^{\mathrm{a}} \pm 4,15 ; 57,8^{\mathrm{b}}$ & $55,82 \pm 4,24 ; 55,60$ & $0,022^{\mathrm{d}}$ \\
Post & $59,32^{\mathrm{a}} \pm 4,03 ; 60,00^{\mathrm{b}}$ & $58,81 \pm 3,70 ; 58,90$ & $0,056^{\mathrm{d}}$ \\
Delta & $2,13^{\mathrm{a}} \pm 3,70 ; 2,20_{\mathrm{b}}$ & $2,99 \pm 1,64 ; 3.30$ & \\
\hline$P$-value $<0.05$ & $0,001^{\mathrm{c}}$ & $0,001^{\mathrm{c}}$ & \\
\hline $\mathrm{a}=$ Mean \pm Standar Deviasi & $\mathrm{c}=$ Paired T-test & & \\
$\mathrm{b}=$ Median & $\mathrm{d}=$ Independent T-test
\end{tabular}

Based on table 4 the results of the Paired T-Test obtained p value of $0.001<0.05$ which means that the 1000 HPK module and premarital class were effective in increasing premarital WUS attitudes about stunting prevention efforts. Meanwhile, after the T-Test independent difference test obtained $\mathrm{P}$ value of $0.022<0.05$ which means that there is a difference in influence between the two groups after the intervention was given, where based on the mean rank of the treatment group is 59.32 greater than the control group that is 58,81 so that it can be concluded that the administration of the $1000 \mathrm{HPK}$ module is more influential in enhancing premarital WUS attitudes about stunting prevention efforts than granting premarital classes only.

\section{DISCUSSION}

\section{Effect of The First 1000 Days of Life Modules Against Knowledge of Premarital Women About Stunting Prevention}

There is a more significant increase of knowledge scores in intervention groups can occur because the premarital class method is a conventional learning method wherein the material provider is more active than the study participants. Participants studying in premarital classes tend to obtain health information only from the speaker. In addition, participants studying in premarital classes also cannot repeat learning while at home. This is in line with the results of other studies which explain that the implementation of premarital classes needs to be studied more specifically related to the quality and accuracy in the delivery of material that is in accordance with the problem needs of class participants, this study also showed that some respondents complained of getting a premarital class that was not in accordance with the expected needs.(Mohebbi et al., 2014) The results of another study conducted on 250 couples who took a pre-marital class in Iran found that only $8 \%$ of respondents experienced an increase in knowledge levels so that the researchers recommended the existence of media support tools for learning (Moodi, Miri, \& Sharifirad, 2013).

While with the addition of modules makes learning participants able to more actively study independently at home, repeat learning again and practice with the questions contained in the module. Learning participants are also able to evaluate themselves the extent to which the participants' ability to correctly answer the questions contained in the module by looking at the answer keys from the exercises contained in the module. This is in line with the results of another study conducted on female school teachers in Banglore, India which stated that $68.3 \%$ of respondents had less knowledge before giving an intervention, which then increased to $70 \%$ of respondents having good knowledge after being given an independent learning module (Khatry, Joseph, \& Campus, 2017). The results of other studies conducted on 60 pregnant women in Utarakkhand, 


\section{STRADA Jurnal Ilmiah Kesehatan}

DOI: $10.30994 /$ sjik.v9i2.332

ISSN: 2252-3847 (print); 2614-350X (online)

Vol.9 No.2 November 2020 Page.515-522

India also showed that the provision of an independent instructional module in pregnant women effectively increased the knowledge of pregnant women about minor illnesses (Kumar, 2014).

The formation of knowledge consists of several stages, that are knowing, understanding, application, synthesis and evaluation. Education and age are predisposing factors that influence knowledge (Notoadmojo, 2014). Education and age in this study have been controlled with a research design where most of the respondents in this study have a high level of education, this shows the higher the education the more information people get. A theory states that the higher a person's education the more ability to obtain and understand the information obtained. This is in line with the opinion which states that there is a relationship between education level and health status of a person (Pradono \& Sulistyowati, 2014). Other research also states that people with higher education will access more information and the similarity of respondents' education level in a training causes the results of increasing knowledge are not much different (Retnawati, Widajanti, \& Nugrahaeni, 2014).

\section{Effect of The First 1000 Days of Life Modules Against Attitude Of Premarital Women About Stunting Prevention}

Information integration theory states that information plays an important role in the formation of attitudes. The accumulation of information absorbed by a person can have an impact that is changing one's belief in an object, changing the credibility of someone already owned and adding to the new trust that already exists (Notoadmojo, 2014). This is in line with the study of suicide prevention modules in medical students in Hong Kong, the results of the study show providing effective modules that increase respondents' positive attitudes, reduce negative ratings of suicide, reduce stigmatization of suicide phenomena and increase sensitivity to suicide facts. Even respondents in this study propose to complete the learning curriculum in accordance with the learning module (Yousuf, Beh, \& Wong, 2013).

The knowledge gained during premarital classroom learning and self-study at home with modules is also able to improve the attitude of premarital women consistently and difficult to change. this is in accordance with an opinion which states that apart from interpersonal, continuous mass media exposure, information about objects in a certain period of time which is repeated makes an accumulation that accentuates a certain aspect in object valuation.(Notoadmojo, 2014). Attitudes reflect the preferences and beliefs of individuals who have experienced the process of formation through knowledge and experience, individuals who have selectivity in paying attention to objects, given information that is in accordance with their beliefs, preferences and interests in this context beliefs can reject new information, individuals can be influenced by information in formation attitudes, information that can change attitudes that can change individual judgment, information in a positive or negative direction(Pradono \& Sulistyowati, 2014). In addition, other factors that influence attitudes are knowledge, personal experience, age, level of education, influence of others who are considered important in life, culture , mass media, religious institutions, and emotional factors(Notoadmojo, 2014).

Other research also states that individual attitudes and beliefs are formed and modified every time an individual receives new information, then is interpreted and integrated with previous attitudes and beliefs that an individual has (Retnawati et al., 2014). The giving of premarital class with the module makes premarital women had more 


\section{STRADA Jurnal Ilmiah Kesehatan}

DOI: $10.30994 /$ sjik.v9i2.332

ISSN: 2252-3847 (print); 2614-350X (online)

Vol.9 No.2 November 2020 Page.515-522

information than the control group. The exercises contained in the module can also help train and evaluate the learning that has been done. The results of this study are supported by research which states the provision of 1000 HPK modules for cadres can increase the attitude of cadres about prevention and early detection of stunting (Nurhayati, 2019)

\section{CONCLUSION}

The giving of the first 1000 days of life module is more influential in increasing the knowledge and attitudes of premarital WUS about stunting prevention efforts before entering the first 1000 days of life.

\section{REFERENCES}

Amri, S. (2013). Pengembangan dan Model Pembelajaran dalam Kurikulum 2013. Jakarta: PT Prestasi Pustakarya.

Haselow, N. J., Stormer, A., \& Pries, A. (2016). Original Article Evidence-based evolution of an integrated nutrition- focused agriculture approach to address the underlying determinants of stunting. Maternal and Child Nutrition, 12, 155-168. https://doi.org/10.1111/mcn.12260

Jap, J., Sumarmi, S., \& Damayanti, N. A. (2019). Importance of Collaborative Intervention of Preconception Nutrition in Suppressing the Stunting Case in East Nusa Tenggara, Indonesia. Indian Journal of Public Health Research and Development, 10(9), 175179. https://doi.org/10.5958/0976-5506.2019.02517.8

Khatry, R. A., Joseph, B., \& Campus, L. N. (2017). A Study to Evaluate The Effectiveness of Self Instructional Module on Knowledge Regarding Pap Smear Screening among Female Teachers from Selected Schools of Bangalore. International Journal of Health Sciences and Research, 7(7), 171-176.

Kumar, M. L. (2014). Effectiveness of "Self Instructional Module" (SIM) On the Level of Knowledge Regarding Selected Minor Ailments and Their Remedial Measures among Pregnant Women. IOSR Journal of Nursing and Health Science, 3(1), 32-38. https://doi.org/10.9790/1959-03143238

Mohebbi, P., Malekpour, P., Kamalifard, M., Atri, shirin B., Safaeiyan, A., \& Alizadeh, K. (2014). Clients' viewpoints about the quality of services in the premarital counseling classes in Tabriz health centers. International Journal of Preventive Medicine 5, 5(3), 365-369. Retrieved from https://www.ncbi.nlm.nih.gov/pmc/articles/PMC4018648/

Moodi, M., Miri, M. R., \& Sharifirad, G. R. (2013). The effect of instruction on knowledge and attitude of couples attending pre-marriage counseling classes. Journal of Education and Health Promotion, 2(55). https://doi.org/10.4103/22779531.119038

Notoadmojo, S. (2014). Promosi Kesehatan dan Perilaku Kesehatan (Edisi Revi). Jakarta: Rineka Cipta.

Nurhayati, Y. (2019). Pengembangan Modul Cetak 1000 Hari Pertama Kehidupan Untuk Pelatihan Kader Bina Keluarga Balita Di BKKBN. Jurnal Ilmiah VISI PGTK PAUD Dan Dikmas, 14(1). https://doi.org/DOI: doi.org/JIV.1401.3

Pradono, J., \& Sulistyowati, N. (2014). Hubungan antara Tingkat Pendidikan , Pengetahuan tentang Kesehatan Lingkungan , Perilaku Hidup Sehat dengan Status Kesehatan Studi Korelasi pada Penduduk Umur 10 - 24 Tahun di Jakarta Pusat. Buletin Penelitian Sistem Kesehatan, 17(1), 89-95. Retrieved from 


\section{STRADA Jurnal Ilmiah Kesehatan}

DOI: $10.30994 /$ sjik.v9i2.332

ISSN: 2252-3847 (print); 2614-350X (online)

Vol.9 No.2 November 2020 Page.515-522

https://media.neliti.com/media/publications/20885-ID-correlation-between-educationlevel-knowledge-of-environmental-health-healthy-be.pdf

Pusat Data dan Informasi Kementerian Kesehatan RI. (2018). Situasi Balita Stunting di Indonesia. Pusat Data Dan Informasi Kementerian Kesehatan RI.

Retnawati, S. A., Widajanti, L., \& Nugrahaeni, S. A. (2014). Pengaruh Pelatihan dengan Metode Simulasi Terhadap Keberhasilan Penerapan Makan Beraneka Ragam oleh Kader Pendamping (Studi di Kecamatan Trawas Kabupaten Mojokerto) The Effect of Training by Simulation Method on Cadres to the Successfulness of Diversity. Jurnal Manajemen Kesehatan Indonesia, 2(3), 212-220. https://doi.org/doi.org/10.14710/jmki.2.3.2014.\%25p

Sanghvi, T., Haque, R., Roy, S., Afsana, K., Seidel, R., Islam, S., ... Baker, J. (2016). Original Article Achieving behaviour change at scale : Alive \& Thrive' $\mathrm{s}$ infant and young child feeding programme in Bangladesh. Maternal and Child Nutrition, 12(1), 141-154. https://doi.org/10.1111/mcn.12277

Young, M. F., Nguyen, P. H., Gonzalez Casanova, I., Addo, O. Y., Tran, L. M., Nguyen, S., ... Ramakrishnan, U. (2017). Role of preconception nutrition in offspring growth and risk of stunting across the first 1000 days in Vietnam. PloS One, 71(Supplement 2), 538. https://doi.org/10.1159/000480486

Yousuf, S., Beh, P. S. L., \& Wong, P. W. C. (2013). Attitudes towards suicide following an undergraduate suicide prevention module: Experience of medical students in Hong Kong. Hong Kong Medical Journal, 19(5), 377-385. https://doi.org/10.12809/hkmj133950 